\title{
REPRESENTASI KEHIDUPAN ANAK DALAM WACANA LIRIK LAGU BERTEMA BROKEN HOME
}

\author{
Ferdian Achsani ${ }^{1 凶}$ \\ ${ }^{1}$ Institut Agama Islam Negeri (IAIN) Surakarta \\ 1dwikurniawan219@gmail.com
}

\begin{abstract}
Song lyrics and music are part of a continuous discourse. With the presence of song lyrics accompanied by music will give its own influence, and vice versa. Song lyrics present as expressions of feeling written by the author. This study aims to describe the impact of divorce caused by parents in children, which is reflected in the song lyrics that represent the lives of children who are victims of broken home. This research is included in qualitative descriptive research with content analysis methods (content analysis). The data validity technique uses persistence techniques. Some of the song lyrics that are the object of this study include 1) Korban Wong Tuwo, 2) Diary Depresiku, 3) Cerita Anak Jalanan, 4) Kemana Kasih Sayang. The results obtained from the analysis of some of the best song lyrics are that parents play a big role in shaping the child's personality. The song lyrics that have been mentioned represent that divorce that occurs by both parents has an impact as children lack love, children become dissidents, ignorant, and children lose their future.
\end{abstract}

Keywords: representation, song lyrics, discourse

Abstrak : Lirik lagu dan musik adalah bagian dari wacana yang bertalian. Dengan hadirnya lirik lagu yang diiringi musik akan memberikan pengaruhnya sendiri, dan sebaliknya. Lirik lagu hadir sebagai ungkapan perasaan yang ditulis oleh penulis. Penelitian ini bertujuan untuk mendeskripsikan dampak perceraian yang disebabkan oleh orang tua pada anak yang tercermin dalam lirik lagu yang mewakili kehidupan anak-anak yang menjadi korban broken home. Penelitian ini termasuk dalam penelitian deskriptif kualitatif dengan metode analisis isi (content analysis). Teknik validitas data menggunakan teknik ketekunan. Beberapa lirik lagu yang menjadi objek penelitian ini antara lain 1) Korban Wong Tuwo, 2) Diary Depresiku, 3) Cerita Anak Jalanan, 4) Kemana Kasih Sayang. Hasil yang diperoleh dari analisis beberapa lirik lagu terbaik adalah bahwa orang tua memainkan peran besar dalam membentuk kepribadian anak. Lirik lagu yang telah disebutkan menunjukkan bahwa perceraian yang terjadi oleh kedua orang tua berdampak karena anak-anak kurang cinta, anakanak menjadi pembangkang, bodoh, dan anak-anak kehilangan masa depan mereka.

Kata Kunci : representasi, lirik lagu, wacana 
Volume 1, Nomor 2, Juli 2019

ISSN 2655-3031 (P), 2655-7851 (O)

\section{Pendahuluan}

Musik merupakan bunyi atau kesan sesuatu yang ditangkap oleh indra pendengar (Pujiharto, 2012:13). Musik dapat digunakan oleh manusia sebagai tempat untuk mencurahkan perasaan dan ekspresi diri, sehingga musik dapat dikatakan sebagai bentuk perwakilan perasaan. Musik terbentuk melalui iringan suatu alat musik atau gabungan dari alat musik yang beragam sehingga mampu menciptakan sebuah irama yang padu dan menghasilkan bunyi-bunyian indah yang dapat dinikmati oleh indra manusia. Fungsi dari musik sendiri beragam mulai dari untuk menghibur, menghilangkan stres, terapi atau pengobatan, sarana dakwah dll. Misalnya musik yang memiliki alunan rancak dapat digunakan sebagai hiburan, musik yang memiliki alunan klasik digunakan untuk meningkatkan konsentrasi anak, dll. Melalui alunan-alunan musik tersebut, munculah beragam jenis aliran musik seperti dangdut, jazz, keroncong, pop, rock, hip hop dll.

Suatu musik dapat lebih dinikmati lagi apabila digabungkan dengan paduan lirik yang serasi dengan musik yang dibawakan. Penggabungan antara musik dan lirik tersebut dapat disebut sebagai lagu. Lirik dalam lagu dibuat sebagai bentuk perwakilan perasaan seorang penyair maupun imajinasi penyair yang ditulis melalui penghayatan yang dalam. Pranawengtyas (2014) menyatakan bahwa lirik lagu merupakan tempat bagi pengarang sebagai bentuk ekspresi diri dalam menjalani kehidupan sehari-hari. Tidak hanya sebagai bentuk perwakilan isi hati penyair, namun melalui lirik lagu juga dapat digunakan sebagai media komunikasi. Hal itu termasuk dalam salah satu fungsi sastra sebagai komunikasi dengan pendengar atau pembaca (Jabrohim, 2014:15).

Sebagai bentuk ekspresi diri, suara dan musik juga dapat dikatakan sebagai wacana (Wijana \& Rohmadi, 2009). Wacana merupakan satuan gramatikal tertinggi, terbesar, utuh dan lengkap, di atas kalimat, paragraf, dialog maupun percakapan. Analisis wacana merupakan kajian yang meneliti penggunaan bahasa dalam berkomunikasi, baik secara lisan maupun secara tulis. Chaer (2012) berpendapat bahwa dalam setiap berkomunikasi menggunakan bahasa, setiap wacana mengandung konsep gagasan pikiran ide yang utuh dan dapat dipahami oleh pembaca . Hal tersebut memunculkan tema dalam sebuah wacana yang ditulis.

Tema dalam wacana lirik lagu menjadi poin pokok dalam pembawaan lagu. Tema merupakan maksud dalam pembawaan sebuah cerita. Tema juga dapat dikatakan sebagai ide pokok dalam sebuah wacana yang dituliskan. Beberapa tema yang muncul dalam lirik lagu seperti percintaan, religi, hingga lagu yang bertema perjuangan hidup. Salah satu dari beragam tema lagu yang menarik adalah lagu yang bertema perjuangan hidup. Dikatakan sebagai lagu yang menarik karena lagu tersebut mengajarkan kepada pendengar untuk lebih menghayati kehidupan. Melalui lagu-lagu yang bertema demikian maka penyair mengajak pendengar untuk mengambil intisari pembelajaran dari lagu tersebut. Tetapi sekarang ini jarang sekali ditemukan penyair yang menciptakan lagu bertema seperti ini. Padahal melalui lagulagu yang bertema perjuangan hidup, pendengar dapat mengambil pembelajaran darinya untuk diimplementasikan dalam kehidupan pribadi pendengar. Beberapa lagu yang menceritakan tentang perjuangan hidup misalnya Cerita Anak Jalanan yang dinyanyikan oleh grup Debu Jalanan, Diary Depresiku yang dinyanyikan oleh Last Child, Korban Wong Tuwo dinyanyikan oleh Eny Sagita dan Kemana Kasih Sayang dinyanyikan oleh Tegar. Beberapa lagu tersebut memiliki kesamaan tema, tentang kisah kehidupan anak yang ditinggal pergi oleh orang tua, meskipun dalam pembawaan cerita yang berbeda dan dengan genre yang berbeda-beda.

Beberapa lagu yang telah disebutkan tersebut di atas menceritakan tentang 
Volume 1, Nomor 2, Juli 2019

ISSN 2655-3031 (P), 2655-7851 (O)

kehidupan seorang anak yang menjadi korban broken home. Beberapa lagu yang disebutkan tersebut menceritakan dampak yang terjadi dari perceraian yang dilakukan oleh kedua orang tuanya terhadap anak. Hubungan suami istri harus harmonis. Keharmonisan orang tua akan membentuk kepribadian anak yang baik (Prawira, 2013). seorang anak selalu membawa pengaruh atau ajaran yang diberikan oleh orang tua. Orang tua bertanggung jawab penuh atas kesuksesan dan tingkah laku yang diraih oleh anak. Yusuf (2014) menyatakan bahwa setiap orang tua apabila telah melahirkan anak-anaknya maka terpikulpada pundaknya satu beban atau kewajiban untuk mendidik serta mengasuh sehingga mereka dapat mandiri. Terutama seorang ayah. Sebagai kepala keluarga ia harus pandai dalam membimbing anak dan istrinya agar betah dirumah dan ikhlas dalam menajlankan segala kewajibannya (Sugihastuti \& Suharto, 2005:87).

Perceraian yang terjadi dari kedua orang tua akan berdampak buruk pada perkembangan anak. Aziz (2015) menyatakan bahwa anak-anak yang menjadi korban broken home keadaannya sangat merisaukan. Mereka yang masih sekolah atau mengenyam bangku sekolah sangat terganggu dalam proses pembelajaran. Orang tua sebagai contoh anak dalam kehidupan sehari-hari harus memberikan teladan yang baik bagi anak. Jika orang tua bercerai, maka siapa yang akan memberikan teladan yang baik bagi anak? Untuk itulah orang tua harus bersikap bijak dalam menghadapi segala masalah yang mampu membuat hubungan rumah tangga mereka hancur. Dalam penelitian yang dilakukan oleh Untari, Kanissa, \& Muhammad, (2018) menyimpulkan bahwa dampak negatif yang ditimbulkan oleh perceraian orang tua seperti malu dengan perceraian orang tua, egois dan keras kepala, sulit fokus terhadap sesuatu, kehilangan rasa hormat terhadap orang tua dan mudah menyalahkan orang tua, salah dalam mengambil keputusan, sering tidak peka terhadap lingkungan, tidak memiliki etika dalam bermasyarakat, tidak memiliki tujuan hidup, ingin menang sendiri, merasa tidak aman dengan lingkungan sekitar karena tidak ada orang tua yang melindung.

Dari uraian yang telah dijabarkan tersebut maka penelitian ini bertujuan untuk mendeskripsikan dampak perceraian orang tua terhadap anak, yang tercermin dari lirik lagu. Penelitian sebelumnya yang relevan dengan penelitian ini pernah dilakukan oleh Susamto (2018). Dalam penelitian tersebut Sumanto mendeskripsikan lirik lagu yang merepresentasikan kesalehan dalam aksi bela islam 212. Hasil penelitian menunjukkan bahwa lagu-lagu yang telah dianalisis tersebut merepresentasikan aksi bela islam yang dihadirkan untuk menguatkan semangat dan solidaritas umat islam. Persamaan dengan penelitian yang akan dilakukan dengan penelitian tersebut adalah objek kajian dan tema yang diteliti. Pada penelitian Susamto mendeskripsikan lirik lagu yang mencerminkan aksi bela islam 212. Penelitian yang akan dilakukan ini bertujuan untuk mendeskripsikan kisah hidup seorang anak yang menjadi korban perceraian orangtua.

\section{Metode Penelitian}

Penelitian ini termasuk dalam penelitian deskriptif kualitatif. Moleong (2013) mendefinisikan penelitian kualitatif sebagai penelitian yang mendeskripsikan data berupaka kata-kata ataupun gambar. Data dalam penelitian ini adalah lirik lagu yang merepresentasikan kehidupan anak yang menjadi korban broken home. Beberapa judul lagu yang menjadi objek penelitian ini diantaranya: Cerita Anak Jalanan yang dinyanyikan oleh grup Debu Jalanan, Diary Depresiku yang dinyanyikan oleh Last Child, Korban Wong Tuwo dinyanyikan oleh Eny Sagita dan Kemana Kasih Sayang dinyanyikan oleh Tegar. Teknik analisis dalam penelitian ini yaitu analisis isi. Analisis isi merupakan penelitian yang berusaha untuk mengetahui isi dan makna dalam suatu dokumen. Teknik 
Volume 1, Nomor 2, Juli 2019

ISSN 2655-3031 (P), 2655-7851 (O)

keabsahan data dalam penelitian ini menggunakan teknik ketekunan, yaitu dengan mengulang secara berkala hasil analisis yang telah ditemukan hingga data dapat dikatakan valid. Adapun langkah yang dilakukan dalam penelitian ini yaitu: peneliti mengumpulkan data atau lagu-lagu yang menjadi objek penelitian, kemudian peneliti mendeskripsikan isi dari setiap lagu tersebut dan yang terakhir peneliti melakukan penarikan kesimpulan.

\section{Hasil dan Pembahasan}

\section{Korbane Wong Tuo Eny Sagita}

Aku tansah eling pungkasane welingmu

Bapak bakal lungo ninggal aku lan ibu

Emboh nyang ndi parane aku ora ngerteni

Netes iluhku nelesi pipiku

Sak pungkurmu uripku tansah gowo sepi

Ibu soyo bingung getun ra mari-mari

Ilang ono sing ilang sakjroning ati iki

Lungamu ora tak lilakne

Pak opo salahe ibu

Kowe nganti tego ninggal anakmu

Pak aku kangen bapak

Pengen bali kumpul dadi siji

Opo ora kroso anakmu iki nelongso

Opo pancen tego aku entok bapak

liyo

Aku emoh dadi korbane wong tuwo

Ndang baliyo ibu isih gelem nrimo

Dalam bait pertama pada lirik lagu Korban Wong Tuo tersebut menceritakan tentang kisah seorang anak yang selalu mengingat pesan ayahnya. Aku tansah eling pungkasane welingmu dalam bahasa Indonesia dapat diartikan sebagai aku selalu teringat akan pesan mu. Dalam hal ini, sang anak selalu teringat pesan dari ayahnya yang akan pergi meninggalkan ibu dan juga dirinya (anak). Sang anak tidak menceritakan tujuan pergi sang ayah, karena dia memang tidak diberi tahu kemana ayahnya akan pergi. Hal itu membuat sang anak bingung harus mencari kemana karena tidak memiliki tujuan yang pasti, hanya bisa menangis karena meratapi kesedihannya.

Dalam bait kedua lirik lagu tersebut menceritakan tentang kesepian yang dialami sang anak setelah kepergian ayahnya. Dalam hal ini sang anak menceritakan bahwa sepeninggalan ayahnya ia merasa bahwa kehidupannya kini merasa ada yang berbeda. Kesepian yang ia rasakan, bukan suasana senang ataupun gembira. Seorang anak jika masih di tunggu oleh kedua orang tuanya maka akan mendapat perhatian dan kasih sayang yang lebih, sehingga mereka bisa merasa senang dan bahagia dalam menjalani kehidupan sehari-hari. Hal tersebutlah yang ingin disampaikan dalam bait tersebut. Kasih sayang dan perhatian yang selalu didapatkannya sudah tidak lagi ia rasakan sehingga ia merasa ono sing ilang sakjroning ati iki (ada yang hilang dalam hati ini). Selain itu dalam bait tersebut juga menceritakan bahwa sang ibu juga mengalami getun (kecewa) yang tiada henti meratapi kepergian suaminya. Rasa cinta sang ibu kepada ayah yang begitu besar membuat sang ibu tidak bisa menahan rasa kecewa karena ditinggal pergi.

Dalam bait ke tiga tersebut sang anak bertanya kepada ayahnya menegenai kesalahan yang diperbuat oleh ibunya, sehingga ia tega meninggalkan anak dan juga ibu. Dalam lirik tersebut tergambarkan bahwa sang anak benar-benar terpukul atas kepergian ayahnya. Sang anak merasa rindu dan kangen serta ingin kembali bertemu untuk berkumpul kembali menjadi keluarga yang harmonis.

Dalam bait terakhir tersebut berisi teguran yang ditujukan kepada ayahnya. Sang anak menegur ayahnya bahwa ia sekarang mengalami Nelongso (prihatin) akibat dari perbuatan ayahnya. Dalam bait tersebut terdapat bentuk kalimat pertanyaan 
Volume 1, Nomor 2, Juli 2019

klarifikasi, yang ditujukan untuk ayahnya dan bertujuan untuk meminta penjelasan darinya, dimana bentuk Kalimat tersebut terdapat pada lirik Opo pancen tego aku entok bapak liyo (apa memang tega kalau aku mendapatkan ayah yang lain?). Dalam hal ini sang anak ingin meminta penjelasan apakah memang sang ayah tega jika melihat Ibu dari anaknya menikah lagi dan anaknya mendapatkan ayah pengganti. Sang anak tidak ingin jika ibunya menikah lagi dan mendapatkan ayah pengganti. Sang anak hanya ingin ayah dan ibunya bisa kembali bersama seperti dahulu. Sang anak juga memberi tahu bahwa ibunya masih mencintai dan mau menerima kembali jika sang ayah ingin kembali bersama lagi. Sang anak tidak ingin jika ia menjadi korban perceraian kedua orang tua nya.

\section{Lirik Lagu Kemana Kasih Sayang - Tegar}

Ayah,

dengarkanlah kurindu padamu

Ibu,

dengarkanlah kusayang padamu

Namun tak lagi dapat kurasakan

hangat belaian kasihmu

Rindu

aku rindu peluk ayah ibu

Kini

hilang sudah ceria hidupku

pada siapa ku harus mengadu

kini aku sendiri

Aku anak jalanan yang terbuang tanpa belaian, kedua orang tua $\mathrm{ku}$ mereka berpisah karena keadaan membuat hidupku berantakan ...

Tuhan Tolong beri aku petunjuk ... kembalikan keindahan yang pernah kurasa

ku hanya bocah kecil yang tak berdaya Tuhan kumohon padaMU
ISSN 2655-3031 (P), 2655-7851 (O)

Lirik lagu tersebutmenceritakan kisah seorang anak yang merindukan kasih sayang dari orang tua. Seorang Anak yang seharusnya mendapatkan kasih sayang dan perhatian dari orang tua tak lagi ia rasakan. Hal tersebut dikarenakan perpisahan yang terjadi pada kedua orang tuanya. Perpisahan yang terjadi di sini dapat dikatakan juga karena suatu perceraian. Pada kalimat kembalikan keindahan yang pernah kurasa merupakan permintaannya pada Tuhan agar dikembalikan keutuhan keluarganya yang pernah dirasakan oleh sang anak. Dalam bait terakhir tersebut menandakan bahwa kedua orangtuanya masih hidup, dan sang anak menginginkan untuk dapat kembali bersatu.

Dalam lirik ini juga menceritakan akibat dari perceraian yang dilakukan oleh kedua orang tuanya. Salah satu akibat tersebut adalah sang anak menjadi anak jalanan. Jika kita melihat beberapa kasus anak-anak jalanan, mungkin lagu ini mewakili perasaan mereka. Banyak anakanak jalanan di pinggir jalan yang bekerja sebagai pengamen pergi dari satu mobil ke mobil yang lain demi mendapatkan uang untuk makan, untuk bisa melangsungkan kehidupan. Bahkan terkadang uang yang mereka dapatkan sering diambil oleh preman-preman yang berkuasa di derah tertentu. Maka dalam lirik tersebut terdapat frase hidupku berantakan yang menandakan bahwa hidup sang anak kini sudah hancur, kacau karena sudah tidak lagi merasakan perhatian dan juga nikmat kasih sayang dari kedua orang tuanya. Anak yang seharusnya belajar dan membantu pekerjaan orang tua di rumah, kini harus merasakan beban berat mencari nafkah dan hidup tak tentu arah di jalanan demi kelangsungan hidupnya.

Meskipun menjalani kehidupan yang pahit, sang anak tak pernah lupa bahwa ia masih mempunyai Tuhan. Dalam lirik Tuhan Tolong beri aku petunjuk dan Tuhan kumohon padaMU tersebut seakan menandakan bahwa sang anak memiliki sisi religius. Ia menyadari bahwa ia tidak bisa menjalani masalah dalam kehidupannya sendiri tanpa bantuan dari Tuhan. Sebab 
Volume 1, Nomor 2, Juli 2019

ISSN 2655-3031 (P), 2655-7851 (O)

sang anak percaya bahwa masih ada tuhan yang akan membantu menyelesaikan segala urusannya selagi ia mau mengadu dan memohon. Maka dari itu sang anak hanya bisa pasrah dan memohon kepada tuhan agar ia diberikan petunjuk untuk bisa mengembalikan kebahagiaan keluarganya yang dulu pernah dirasakannya.

\section{Lirik Cerita Anak Jalanan}

bapakku kawin lagi

ibuku seorang diri

jadilah aku beigni

mata gelap ku bernyanyi

dimana uang, dimana lapar

dimana nasi, aku mencari kehidupan

mabuk ganja dan minuman

itu pelarianku

banyak warna tinta di tubuhku

aku tersesat jalan

jadilah aku anak jalanan

jadilah aku cibiran orang di terminal

cerita anak anak jalanan korban

kemunafikan

tak ada masa depan yang mapan untuk

diperjuangkan

kasih sayangnya yang diabaikan

kasih sayangnya yang dilupakan

di sini aku masih berdiri

di sini aku tetap bernyanyi di jalanan

Lirik lagu tersebut menceritakan pengalaman kehidupan yang pernah dijalani oleh seseorang yang pernah hidup di jalanan. Subjek dalam lirik tersebut adalah kata "ku". Dalam lirik lagu tersebut menceritakan tentang kehidupannya yang kini sudah jauh dari kata keharmonisan. Semenjak ditinggal pergi oleh ayahnya, yang memilih kawin (menikah) dengan wanita lain, kini ibunya pun sebatang kara berusaha untuk bisa membesarkan anaknya dengan segala kemampuan yang dimilikinya. Frasa mata gelap dalam lirik lagu tersebut menggambarkan bahwa sang anak tidak bisa berpikir tenang dan logis hingga akhirnya ia pun mencari uang, nasi dan kehidupan untuk memenuhi kehidupannya.

Karena merasa bahwa terlalu berat beban derita yang harus dihadapinya, sang anak pun melakukan berbagai cara agar bisa terhindar dari beban tersebut. Sang anak merasa bahwa dengan mengonsumsi minuman keras, ganja hingga mabuk akan membuat semua beban yang dialaminya mudah teratasi. Tetapi semua itu tidak membuahkan hasil justru menambah masalah baginya. Semakin larut dalam hidup yang sedemikin, maka kehidupan anak menjadi semakin ambruladul (berantakan). Kehidupannya kini dijalanan, di pinggir terminal hingga menjadi kembang lambe atau kembang kocapan (bahan pembicaraan) semua orang. Pemilihan tempat terminal sebagai tempat pelarian dalam lirik lagu tersebut, menggambarkan sesuai realitias kehidupan bahwa terminal seakan menjadi tempat bagi meraka yang kelihangan arah untuk pulang. banyak preman-preman ataupun anak jalanan yang suka nongkrong di pinggir terminal.

Dalam lagu ini, sang anak menceritakan bahwa ia adalah korban kemunafikan dari kedua orangtuanya. Dikatakan sebagai korban kemunafikan karena kedua orang tuanya yang tidak menepati janji. Salah satu ciri orang munafik adalah apabila ia berucap selalu berdusta. Kehidupan semua pasangan suami istri sebelum mereka menikah pasti saling mengucap janji untuk sehidup-semati. Namun setelah mereka bercerai, janji yang mereka buat mereka ingkari sendiri. Hal tersebutlah yang mendasari mengapa tokoh aku dalam lirik lagu tersebut mengatakan bahwa dirinya merupakan korban kemunafikan. Akibat dari apa yang diperbuat oleh kedua orangtuanya tersebut, kehidupan sang anak pun menjadi korban. Sang anak memilih untuk tinggal di jalanan dan bernyanyi di sana untuk memenuhi kehidupannya. Sedangkan masa depan yang seharusnya cerah dijalani oleh anak harus 
terkubur karena sang anak tidak memiliki masa depan yang indah untuk diperjuangkan karena ia sekarang hidupnya hanya bergantung pada jalanan. Bahkan pendidikanpun tidak ia dapatkan sehingga hidupnya tidak lagi berarti baginya.

\section{Diary Depresiku - Last Child}

Malam ini hujan turun lagi Bersama kenangan yang ungkit luka di hati

Luka yang harusnya dapat terobati Yang ku harap tiada pernah terjadi

$\mathrm{Ku}$ ingat saat Ayah pergi, dan kami mulai kelaparan Hal yang biasa buat aku, hidup di jalanan

Disaat ku belum mengerti, arti sebuah perceraian

Yang hancurkan semua hal indah, yang dulu pernah aku miliki

Wajar bila saat ini, ku iri pada kalian Yang hidup bahagia berkat suasana indah dalam rumah Hal yang selalu aku bandingkan dengan hidupku yang kelam Tiada harga diri agar hidupku terus bertahan

Mungkin sejenak dapat aku lupakan Dengan minuman keras yang saat ini $\mathrm{ku}$ genggam Atau menggoreskan kaca di lenganku Apapun kan ku lakukan, ku ingin lupakan

Namun bila ku mulai sadar, dari sisa mabuk semalam Perihnya luka ini semakin dalam ku rasakan

Disaat ku telah mengerti, betapa indah dicintai

Hal yang tak pernah ku dapatkan, sejak aku hidup di jalanan
Volume 1, Nomor 2, Juli 2019

ISSN 2655-3031 (P), 2655-7851 (O)

Sama dengan yang lainnya, lirik lagu berjudul Diary Depresiku tersebut juga menceritakan tentang kesedihan seorang anak yang juga menjadi korban kemunafikan dari kedua orang tuanya. Dalam lagu tersebut juga menceritakan tentang sosok ayah yang pergi meninggalkan anaknya. Kepergian sang ayah yang tak pernah sekalipun diharapkan oleh sang anak, justru harus terjadi dan membuat kesedihan yang mendalam bagi sang anak. Kepergian tersebut membuat luka di hati sang anak yang tidak dapat terobati oleh obat apapun.

Semenjak kepergian sang ayah, kini sang anak pun mulai kelaparan. Hal tersebut sangat wajar jika dihadapi oleh anak manapun yang ditinggal pergi oleh orang tua terutama seorang ayah. Seorang ayah seharusnya berkewajiban untuk menafkahi, membimbing, merawat dan membesarkan anak, bukan malah meninggalkan dan menelantarkan anak. Akibat dari perbuatan tersebut berdampak pada anak harus hidup mandiri dan berusaha menghidupi kehidupannya sendiri. Salah satunya yang sering ditemui yaitu anak-anak sering menjadi anak jalanan.

Akan tetapi kehidupan anak jalanan tidak membuat kehidupannya bahagia, justru membuatnya semakin meratapi kesedihan. Kehidupan yang semulanya enak dan tidak pernah merasakan susahnya mencari nafkah, kini ia harus mengalaminya. Dalam hal ini sang anak ingin melupakan semua konflik yang ia alami. Salah satunya yaitu dengan meminum minuman keras. Minuman keras dijadikan pilihan sebagai pelarian karena dengan mengkonsumsi minuman tersebut, sang anak berharap agar pikirannya bisa terbebas dari segala persoalan yang dideritanya. Selain dengan minuman keras, dalam lirik tersebut juga diceritakan salah satunya yaitu dengan menggoreskan kaca pada lengan tangan. Bagi sebagian orang, menggoreskan kaca merupakan bentuk frustasi seseorang karena terlalu berat memikirkan beban hidup yang dideritanya. Sang anak hanya ingin 
Volume 1, Nomor 2, Juli 2019

ISSN 2655-3031 (P), 2655-7851 (O)

melupakan semua masalah ataupun konflik yang dialaminya dengan berbagai cara tanpa berfikir panjang akan apa yang ia alami.

Anak merupakan amanah yang diberikan oleh Tuhan yang menjadi tanggungjawab orang tua untuk dirawat, dijaga, dididik dan dibesarkan. Sebagai orang tua hendaknya selalu memberikan perhatian dan bimbingan kepada anak. Orang tua seharusnya memberikan pengalaman yang pernah dilakukannya kepada anak sebagai bentuk pendidikan sekaligus menghargai segala usaha dan kerja keras yang dilakukan oleh anak (Roesli, Ahmad, \& Aina, 2018). Peribahasa jawa mengatakan bahwa anak polah bapak kepradah. Peribahasa tersebut memiliki makna bahwa apapun perbuatan yang dilakukan oleh anak, setiap orang tua pasti menanggung akibatnya. Untuk itu orang tua memiliki tanggung jawab yang penuh sebagai pendidik sekaligus teman bagi anak. Orang tua atau keluarga merupakan tempat utama bagi anak dalam mendapatkan pengetahuan dan tempat bagi anak untuk berlindung. Dalam keluarga anak akan mendapat nilai-nilai kehidupan yang tidak didapatkan di sekolah dan mendapatkan kasih sayang dari orang tua.

Setiap anak yang terlahir di dunia adalah dambaan dan harapan semua orang tua. Pasangan suami istri yang belum dikaruniai seorang anak, selalu berusaha bagaimanapun caranya agar bisa mendapatkan keturunan (anak). Namun tidak dapat dipungkiri bahwa masih banyak orang tua yang lalai dalam menjalankan tugasnya sebagai pendidik yang utama bagi anak. Orang tua memiliki tugas untuk mendidik, merawat, dan membersarkan anak sampai seorang anak dikatakan mampu untuk hidup secara mandiri. Bahkan ketika nanti di akhirat, orang tua akan dipertanyakan mengenai tanggung jawabnya dalam mendidik anak. Pola asuh yang diberikan oleh orang tua kepada anaknya, turut mempengaruhi perkembangan karakter anak. tidak hanya soal karakter anak, pola asuh orangtua juga berpengaruh terhadap prestasi belajar anak. Hal itu disampaikan oleh Ningrum (2017) bahwa terdapat pengaruh positif yang signifikan pada pola asuh orang tua terhadap prestasi belajar anak. Jika anak diasuh dalam pola asuh yang serba dikengkang, maka akan menghasilkan anak yang penakut dan minder. Jika anak diasuh dalam pola asuh yang lepas, maka anak akan berbuat semaunya sendiri.

Selain orang tua, peran lingkungan dalam perkembangan anak juga sangat berpengaruh. Lingkungan akan menjadi penentu perkembangan karakter anak. Baik buruknya lingkungan perkembangan anak turut mempengaruhi perkembangan karakter anak. Terlebih lagi jika anak jauh dari perhatian orang tua. Anak tidak dapat merasakan perhatian, sehingga ia mudah terpengaruh oleh lingkungan bergaul yang salah dan akibatnya akan jauh dari moral sosial di masyarakat. Salah satu faktor yang sering terjadi mengapa anak kurang mendapat perhatian dari orang tua adalah akibat dari adanya perceraian. Perceraian biasanya disebabkan karena faktor ekonomi, perselingkuhan, permasalahan sepele antara kedua orang tua, dll. Perceraian dalam agama (islam) memang tidak dilarang, akan tetapi perceraian sangat dibenci oleh Allah. Hal ini dikarenakan yang akan menjadi korban dan yang akan menderita adalah anak. Adanya kasus perceraian yang terjadi antara kedua orang tua dapat mempengaruhi psikologi anak. Mereka merasa terluka dan sering tidak mendapatkan perhatian dan kasih sayang dari orang tua.

Beberapa lirik lagu yang sudah dijabarkan tersebut di atas adalah sebagai contoh bahwa orang tua memegang peranan penting dalam mendidik anak. Akibat dari perceraian orang tua akan menyebabkan beberapa masalah. Pertama, kurang kasih sayang. Sejatinya kehadiran anak merupakan tempat curahan kasih sayang bagi orangtua. Perpisahan dari kedua orang tua dapat menjadi beban tersendiri bagi anak. Terlebih lagi jika anak masih kecil dan butuh perhatian yang lebih dari kedua orang 
tua. Anak akan menjadi kurang mendapat kasih sayang, sehingga yang terjadi adalah anak akan sering murung dan menyendiri. Hal lain yang ditakutkan adalah anak akan salah dalam bergaul apabila luput dari pengawasan. Hal ini tergambar dalam lirik Korban Wong Tuwo dan lirik lagu Kemana Kasih Sayang. Kedua lagu tersebut menceritakan bahwa kehidupannya begitu sepi semenjak kepergian ayahnya. Kasih sayang dari orang tua sangat dirindukan dalam kedua lirik lagu tersebut.

Kedua, anak akan menjadi pribadi yang nekat dan masa bodo. Dalam beberapa lirik lagu di atas, beberapa contoh pribadi yang nekad misalnya adalah anak suka mengkonsumi minuman keras hingga menggoreskan kaca di lengan. Perbuatan yang dilakukan oleh sang anak tersebut berdampak negatif pada diri anak. Dengan mengkonsumsi minuman keras, seseorang selalu berpikir bahwa mereka akan terbebas dari masalah. Bagi mereka, minuman keras adalah jalan untuk memecahkan masalah yang mungkin tengah mendera mereka. Padahal mengkonsumsi minuman keras sangat berdampak negative pada tubuh. Selain melanggar ajaran agama, dampak yang ditimbulkan dari mengkonsumsi minuman keras bagi tubuh misalnya kerusakan otak, penyakit jantung, kanker, masalah paru, gangguan hati, masalah perut dan sistem pencernaan, keracunan. Itulah sebabnya mengapa khamar atau minuman keras dilarang dalam agama untuk dikonsumsi, karena dengan mengkonsumsinya sangat berdampak negatif pada kesehatan tubuh. komunikasi antara orangtua dan anak dalam hal ini sangar diperlukan dan harus terjalin dengan baik, agar orang tua mudah membentuk perilaku anak yang baik (Achsani, 2019).

Dalam lirik di atas juga disebutkan salah satu aksi nekatnya yaitu menggoreskan kaca di lengannya. Perbuatan menggoreskan kaca di lengan pun juga berpengaruh negatif pada seseorang. Jika anak berbuat sedemikian rupa dan tidak ada pertolongan, maka hal tersebut dapat mengakibatkan anak akan kehilangan nyawa (meninggal). Jika hal tersebut sampai terjadi maka dapat dikatakan sebagai bentuk bunuh diri. Biasanya hal tersebut terjadinya karena seseorang merasa frustrasi karena segudang masalah menumpuk yang ia lalui dan sudah tidak memiliki harapan ataupun cara untuk diselesaikan. Padahal jika kita yakin dan mau menyerahkan segala masalah kepada tuhan, pasti ia akan memberikan jalan keluar dari masalah-masalah yang kita lalui.

Ketiga, hilangnya masa depan yang cerah atau bahagia. Masa depan yang bahagia adalah dambaan setiap insan manusia. Tidak ada manusia yang tidak menginginkan masa depan yang bahagia. Kasus perceraian yang terjadi dari kedua orang tua pun berdampak pada masa depan anak. Salah satu contoh yang ditemukan adalah banyak anak-anak yang lebih memilih mengadu nasib menjadi pengamen, preman, pengemis di jalanan. Hal ini dikarenakan tuntutan ekonomi yang mendesak sehingga anak lebih memilih putus sekolah dan bekerja sebagai pengamen di pinggir jalan. Perbuatan tersebut mengakibatkan anak akan kehilangan masa depan yang bahagia karena kurangnya pendidikan. Pendidikan memang bukan penentu kesuksesan, tapi setidaknya dengan adanya pendidikan dapat membuka jalan kesuksesan bagi seseorang. Untuk itu orang tua (ayah) seharusnya memberikan nafkah bagi keluarga. Jika orang tua bercerai, dan tidak memberikan nafkah bagi anak, maka seorang anak tentu akan memilih untuk bekerja dan menghidupi dirinya demi kelangsungan hidup karena hal tersebut merupakan salah satu jalan utama yang dapat dilakukan oleh anak.

\section{Simpulan}

Orang tua merupakan kunci keberhasilan anak. Untuk itu orang tua sangat bertanggung jawab atas tingkah laku ataupun tindak-tanduk yang dilakukan oleh anak. Menjadi anak yang sukses dan dapat membahagiakan orang tua adalah dambaan dari setiap orang tua dan anak. Pola asuh 
dari orang tua sangat berpengaruh terhadap perkembangan anak. Orang tua seharusnya selalu berada di samping anak untuk memberikan didikan, arahan, petunjuk agar anak memiliki budi pekerti yang luhur. Perceraian yang terjadi oleh orang tua sangat berpengaruh pada kehidupan anak. Dari beberapa wacana lirik lagu yang sudah dijabarkan tersebut di atas, dapat ditarik kesimpulan bahwa anak akan kehilangan kasih sayang, berbuat nekat dan masa bodo, serta kehilangan masa depan yang bahagia apabila kedua orang tua mereka bercerai. Dari beberapa wacana lirik lagu tersebut di atas, dapat diambil pembelajaran bahwa perceraian selalu berdampak buruk bagi anak. Hadirnya wacaan lirik lagu bertema Broken Home ini diharapkan dapat menajadi pembelajaran bagi orang tua dan anak untuk selalu menjaga kasih sayang. Orang tua adalah kunci keberhasilan anak, sehingga orang tua harus memberikan dukungan terhadap tumbuh kembang anak. Begitu juga dengan anak, ia harus selalu menyayangi orang tua dan patuh kepada mereka.

\section{Daftar Pustaka}

Achsani, F. (2019). Aspek Moralitas dalam Anime Captain Tsubasa Melalui Penggunaan Tindak Tutur Asertif dan Ekspresif. Lingua, 15(1), 23-35.

Aziz, M. (2015). Perilaku Sosial Anak Remaja Korban Broken Home dalam Berbagai Perspektif (Suatu Penelitian di SMPN 18 Kota Banda Aceh). Jurnal Al Ijtimaiyyah, 1(1), 30-50.

Chaer, A. (2012). Linguistik Umum. Jakarta: PT Rineka Cipta.

Jabrohim. (2014). Teori Penelitian Sastra. Yogyakarta: Pustaka Pelajar.

Moleong, L. J. (2013). Metodologi Penelitian Kualitatif Edisi Revisi. Bandung: PT Remaja Rosdakarya.

Ningrum, W. R. (2017). Pengaruh Peranan dan Pola Asuh Orang Tua Terhadap Hasil Belajar Siswa Sekolah Dasar Negeri (SDN) di Kecamatan Bogor Barat. Jurnal Pendidikan, 17(2), 129137.

ISSN 2655-3031 (P), 2655-7851 (O)

Pranawengtyas, D. R. (2014). Ketegaran Perempuan Dalam Lirik Lagu Aku Rapopo. Multilingual, 13(2), 126-135.

Prawira, P. A. (2013). Psikologi Kepribadian Dengan Perspektif Baru. Jogjakarta: Ar-Ruzz Media.

Pujiharto. (2012). Pengantar Teori Fiksi. Yogyakarta: Penerbit Ombak.

Roesli, M., Ahmad, S., \& Aina, A. (2018). Kajian Islam Tentang Partisipasi Orang Tua dalam Pendidikan Anak. Jurnal Darussalam; Jurnal Pendidikan, Komunikasi Dan Pemikiran Hukum Islam, IX(2), 332-345.

Sugihastuti, \& Suharto. (2005). Kritik Sastra Feminis Teori dan Aplikasinya. Yogyakarta: Pustaka Pelajar.

Susamto, D. A. (2018). Lirik Lagu Dan Representasi Kesalehan Dalam Aksi Bela Islam (The Lyric Of The Songs And The Representation Of Piety In The Defensive Action Of Islam). Kandai, 14(1), 59-76. https://doi.org/10.26499/jk.v14i1.542

Untari, I., Kanissa, P. D. P., \& Muhammad, H. (2018). Dampak Perceraian Orang Tua Terhadap Kesehatan Psikologis Remaja. Profesi (Profesional Islam), 15(2).

Wijana, I. D. P., \& Rohmadi, M. (2009). Analisis Wacana Pragmatik: Kajian Teori dan Analisis. Surakarta: Yuma Pustaka.

Yusuf, M. (2014). Dampak Perceraian Orang Tua Terhadap Anak. Jurnal AlBayan, 20(29), 33-44. 